\title{
Culture Indulgence: Communicating in the Language of Nyonya Cuisine
}

\author{
James B. Kuake and Steffanie G. Kuake
}

\begin{abstract}
Malaysia is a multi-racial nation with an incredible blend of cultures. The Peranakan or Straits-born Chinese are a unique group of a Creole sub-culture in Malaysia. They trace their ancestry to Chinese and local Malays. Also known as Peranakan they are rich in cultural heritage as manifested through their arts, rituals, fashions, and most interestingly, cuisine. Nyonyas refer to Peranakan women. Nyonyas are known for their cuisine which in a nut-shell is a harmonious blend of cultures from two different customs and traditions of their ancestors. By looking at the key ingredients used in Nyonya cuisine, it tells hundreds of stories behind those ingredients and ways of cooking, notwithstanding the delicious output. Despite the Peranakans having settled in various nations around the globe today, they have not forgotten their origins and their sense of pride of their heritage. One manifestation of these is through Nyonya cuisine being made available to family and friends wherever Peranakans have settled. Food communicates culture. What one eats is what one is, and what one eats says a whole lot about who one is. Humankind's identity is symbolized by our food choices. The same goes to what we do not eat nor drink. In addition, our food communicates our identity, beliefs, cultural and social backgrounds to others. It tells a whole lot about a culture as can be told from knowing the origins of ingredients to presentation and plating. In sum, Peranakan food commonly referred to as Nyonya cuisine, while create a new renaissance in the food and beverage, and tourism industry, also communicates the epistemology of that Creole subculture; often indulging both the palate and thirst of cultural awareness.
\end{abstract}

Index Terms-Peranakan, Baba, Nyonya, cuisine, culture, communicate.

\section{INTRODUCTION}

In almost every travel program on television which features Melaka, it is without fail that local food is highlighted and Nyonya cuisine will be among them. Such is the fame of Nyonya cuisine, especially cakes and desserts which collectively is often referred to as Nyonya kueh (cakes). Today, Nyonya cuisine is rather ubiquitous with many restaurants claiming to serve authentic Nyonya food, some even naming their restaurants using the word Nyonya. Such seem the commercial attraction and value of the term Nyonya cooking. Under all that palatable indulgence, much about the origins of Peranakans can be discovered by looking closer the ingredients and recipe of Nyonya cuisine.

Manuscript received July 11, 2017; revised August 11, 2017.

James B. Kuake is with the Department of Communication, Faculty of Social Sciences, Arts \& Humanities, Tunku Abdul Rahman University College, Kuala Lumpur, Malaysia (email: kuakebm@acd.tarc.edu.my).

Steffanie G. Kuake was with Queen Mary College/ University College London, University of London.

\section{THE PERANAKANS: BRIEFLY}

According to Tan [1], "the Peranakans ethnic community began almost 600 years ago when Chinese traders arrived in the Malay Peninsula, the nucleus was Malacca, centre of the Malacca Sultanate". Lee [2] confirmed that the Baba's 'Golden Age' started to grow in the late 19th and 20th century. Significantly, there are three terms which are commonly used to explicate the Babas community. They can be called as the Peranakan, the Straits Chinese, and the Babas and Nyonyas. The word Peranakan' is derived from Bahasa Malaysia the word of 'anak' which refers to the meaning of 'child'. The term means the mixture of the local-born as well as the offspring of foreigner-native union. The term 'Baba' is meant for the male and 'Nyonya' for the female. The Bahasa Malaysia (Malay language) word of 'Baba' derived from the Malay word bapa meaning 'father'. The word 'Nyonya' is believed to have originated from Java [2]. In Malay, 'Nyonya' means 'young lady', whereas 'Bibik' is a term for elderly ladies. Meanwhile, according to $\mathrm{Ng}$ and Abdul Karim [3], the word Peranakan is derived from Indonesia or Malaysia which consist of several meanings. It is noted here that the term Peranakan (literally meaning born in the locality of the Straits Settlements) can be more encompassing which include Indians, Javanese, and Euro-Asians such as those with mixed parentage of local Malays with Portuguese, or Dutch [4]. In synthesis, many historians identify the Peranakans as offspring of intermarriage between Chinese settlers from the Ming trade voyages and local Malay women in the port city of Melaka [5]. Ming Chinese traders and sea farers may have to spend some time in Melaka during inter monsoon periods before continuing their journey either westward toward Indian and Arabia, or during their homeward journey back to south China [6]. Clammer [7] explained in his article about the Peranakans as "the Straits Chinese regarded the Straits Settlements as their homeland and while maintaining a basically Chinese identity, they gradually abandoned close links of kinship, sentiment, political allegiance and financial remittances to China so characteristic of the non-Baba Chinese". Although Peranakans "decorated their houses in conformance with paternal (Chinese) culture, much of their domestic life was deeply influenced by the Malay side of their heritage," wrote Brissenden [8].

\section{LITERATURE REVIEW}

There are many definitions given to the word, culture. Generally, culture refers to everything that people do or practice in the society which involves ideas, values, attitudes or behaviours. Hofstede [9] defined culture as "the 
collective programming of the mind which distinguishes the members of one group from another", which is passed from generation to generation, it is changing all the time because each generation adds something of its own before passing it on. In another context, culture is a set of shared and continuing for its values, beliefs that shaped identity, ethnic or other groups and get used to their behaviours [10]. Cultural indulgence denotes that individuals who feel that they are blessed and happy over self-controlled of their participation in life activities and practices. The Peranakans have a strong sense of pride and respect for their traditions given its fascinating heritage values. Lee [11] defined the Peranakan culture as a "unique blend of two dominant cultures; Malay and Chinese-intermixed into a fascinating synthesis with elements of Javanese, Batak, Thai and British cultures, representing 'multiculturalism' and 'fusion', long before the latter two terminologies were invented".

The Peranakans are well-known for their rich culture, which are noticeable in way their dressing, food and language. Peranakans preserved most of their traditions and religious origins (such as ancestor worship), but assimilated the culture and language from the Malay communities. In the perspective of Peranakan's food serving for worshiping, it comes in three main functions; as offerings to the Gods and ancestors, to stop vows, celebration of marriages and festivals [12]. Generally, there are three other different kinds of Peranakan namely Jawi Peranakan and Indian Peranakan. Presently, the biggest population of Peranakan communities can be found in Malaysia-most in Malacca and Penang and Singapore [13]. Even though the reality that Peranakans have espoused several elements of local culture and blended in with their lifestyle, yet the representation of their food remains Chinese until now [14]. As claimed by Lee [15], the Peranakan portrayed very much of Malay culture in substance and proudly Chinese in form.

"Fashion is in Europe, living is in America, but eating is in China" [16]. This phrase exemplifies how Chinese people treasure and value food around them. From the perspective of Chinese people, food is an important part of daily life. This is because the Chinese believe that eating and sharing good food can generate harmony and intimacy among family and friends That is why the Chinese communities place high importance on the annual Chinese New Year eve dinner among family members. Due to the uniqueness of the Peranakan communities which is greatly influenced by the Chinese culture, food continues to play a vital role in reflection of perception of oneself and others. However, more often than not, the key role of food has become more complicated [17]. Now, the Peranakans or Nyonya cuisine had undergone the cultural assimilation and become rather fusion to fit into local and for commercial reasons from the social aspect of assimilation between Peranakans and their Malay counterparts in Malaysia. Americo [18], further elaborated that food is the most influential cultural symbol that symbolizes a person's culture. Hence, food can bring people together and as well as becoming a form of comfort in tough times. There is a strong connection between Nyonya cuisine and Chinese symbolism which can be seen in three principles: colour, linguistic association (name of the entrees) and physical association (appearance of the cuisine) [18]. Hall [19], claimed that the Peranakan cuisine merges the cooking techniques from Chinese and in terms of the spices and flavours are taken from Malaysia and Indonesia. This provides fame to Peranakans that their food is equally tangy, aromatic, spicy and herbal.

Lee [20] further defines Peranakan culture "as a culture of "rare and beautiful blend" of two dominant cultures Malay and Chinese with some elements from Javanese, Batak, Siamese and European (specifically English) cultures". Malaysian Peranakan cooking styles are differ and unique of its own taste by regional basis. In short, there are regional variations in Nyonya cooking. For instance, dishes from the northern region of Peninsular Malaysia take in great influences from our neighbouring country, Thailand. The dishes seem to be more sided towards the use of lemongrass, tamarind and other sour ingredients. However, the dishes from Melaka see the greater influence from Indonesia which more liberal use of coconut milk. Literally, the taste of Peranakan food of Melaka, Penang and Singapore are independently unique [21]. Tan [22] also made this distinction between northern and southern Nyonya cuisine. Melaka and Singapore Peranakan cuisine are much inspired by Portuguese and Indonesian taste. Therefore, in the southern region of Peninsular Malaysia, the taste of dishes are generally sweeter and less spicy due to generous amount of coconut milk and Malay spices such as coriander and cumin, compared to the northern region of Peninsular Malaysia [23] where the Thai influence of sour flavour is more dominant.

Traditionally, Nyonya ladies are judged on their cooking capabilities based on the pace a Nyonya lady crushes the spices (rempah) for spicy shrimp paste condiment (sambal belachan) making with mortar and pestle (batu lesung). Sambal belacan is a popular spicy Malaysian chili condiment consisting of chilies, belachan, and lime juice. It adds a spicy zest to the dishes. In the olden days, how quickly a young Nyonya damsel, is able to crush spices using only a mortar and pestle (no electric blenders or mills then), is one of the most important criteria in bride selection for potential daughter in-law [24]. This demonstrates the amount of effort the young Nyonya invests in her cooking regime. In view of that, once again food and ways of preparation are highly emphasized by the Peranakan.

The Peranakans speak a mixture of Bahasa Malaysia and Chinese dialects. Hokkien is the most used dialect by these communities. However, different dialects spoken by the Peranakans may have influence on their cuisine and ways in food preparations. For instance like Cantonese, Teochew and Hakka communities are having different emphasis in ingredients and cooking styles, each uniquely preferred and most practiced by these sub cultural Chinese ethnic groups.

"Food functions effectively as a system of communication because everywhere human beings organize their food ways into an ordered system parallel to other cultural systems and infuse them with meaning" [25]. Meanwhile, the power of food is as a symbol of cultural identity [26]. The world started to have interest on Peranakan cultures during the 1980s [26]. This era started interest to things Peranakan; from their unique historical background, settlement in South East Asia, customs and traditions to food and desserts. This can be seen especially in their food where it gives a rise of attention on Peranakan 
dishes and cakes and desserts (kuehs). According to Lee [27] there are Peranakan communities in Phuket, Indonesia, Laos, Vietnam and Myanmar. It is undeniable that Malaysia is a wonderful multiracial country with rich cultural heritage and a food paradise for food hunters. As people travel to different regions in Malaysia, they encounter different taste of Peranakan cooking which blend with influences of other countries and as well as the key ingredients for different entrees. Interestingly, through food and cuisine, one can foster an appreciative and deeper understanding of an ethnic or cultural group.

The intense pace in globalisation, geographical dispersion and technology advancement with social media and most importantly, ignorance of young generations towards their core ethnic culture have caused fading of the Peranakan culture [28]. However, there exist a strong will among Peranakans to embrace and preserve their unique culture and to pass it down to the next generation [29]. For an instance, the vitality of a culture can be expressed through cuisine which is the best universal language everyone regardless of race or ethnicity can communicate.

\section{The UnTOld BACKGROUND OF NyONYA CUISINE}

The phenomenon of immigrant cuisine has been discussed by many cultural anthropologists. Levenstein [30] summarized that immigrants and ethnic minorities try to maintain their own cooking and eating habits as long as possible". Choice of ingredients, substitution of ingredients and modified preparation techniques are among some of the adaptations migrants have to contend with when resettling to a new land.

Mennell, Murcott, \& van Otterloo [31] defines culinary culture as a "shorthand term for the ensemble of attitudes and tastes people bring to cooking and eating". They postulated that culinary culture is the "development of different tastes over time" stemming from the accepted notion among sociologists and anthropologists that culture is "learnt, shared and transmitted from one generation to another".

The origin and identity of a community may be revealed and obviously seen in the food and ways of its preparation. Nyonya cuisine reflects the cultural identity of the Peranakans. Nyonya cuisine also known as Peranakan cuisine has its own unique taste of due to usage of traditional and local Malay ingredients, employing Chinese cooking techniques. It also reflects both colonial (Portuguese, Dutch and English) and neighbourly influences (Thailand, India and Indonesia) and spices and aroma from turmeric from Malay cooking culture. Tan [32] concluded that "Peranakans or Nyonya cuisine is the creation from cultural that takes place from cultural borrowing and cultural innovation through contact with local ingredients and non-Chinese principles of food preparation". The Peranakans have reserved some of their Chinese roots and as well as absorbing other influences such as Malay, Indian and European [33]. Though many attentions have given by the communities and people all around the world towards Malaysian Peranakans, yet the people including the local communities are in uncertainty about the Peranakan's culture and their existence [34].

Given the mixed parentage ancestry of the Peranakans; Nyonya cooking draws from both local Malay and Chinese styles. Hutton [35] describes Nyonya cuisine as a "happy marriage of Chinese and Malay cuisines". Like any type of cuisine, local ingredients would be the primary and first choice due to ease of availability, even inexpensive due to its abundance. Therefore, local Melaka spices and spices from the Malay archipelago which are traded in Melaka forms the main flavours of Nyonya cuisine. Tan [36] highlighted that Nyonyas "produce food out of their knowledge of Chinese and local indigenous (Malay) styles of cooking with the use of many local ingredients".

Apart from candlenut (a local nut used as a thickener), coconut cream (santan) is also used as thickener for in Nyonya curries and sauces, given the abundant supply of coconuts grown in Melaka. Local spices and herbs such as star anise, turmeric, galangal (lengkuas), and screw pine leave (pandan) are commonly used in Nyonya cuisine. Both spices and chillies are an integral part of Malay cuisine and these are also very popular ingredients in the preparation of Nyonya cuisine. Hot local Malay curries were perhaps toned down with santan resulting with a mild spiced gravy which early Babas would have been "weaned" to accept, even enjoy.

The Peranakans are indeed a very creative ethnic group. They made some changes to traditional Chinese food because of the limited availability of the main ingredients in order to cater to local taste and preferences [37]. According to Tan [38], there are three different categories which can be seen in Nyonya food. The three categories are namely; traditional Chinese Hokkien with slight revision to the ingredients and taste [39]. For instance of traditional Chinese Hokkien such as stir fried vegetables mix with tauchu and dried shrimp (Chap Chai). Second is Malaystyled cooking [40]. For instance the Malay-styled cooking such as Assam Pedas Fish and Beef Rendang. Lastly is the newly innovated foods. For instance such as 'Udang Goreng Asam' (fried tamarind prawns), 'Ayam Pongteh' (chicken stew cooked with tauchu or salted fermented soy beans) [41], 'Ayam Buah Keluak', a special dish combining the chicken with nuts from the Pangium edule or 'kepayang tree', 'Otak-Otak', a famous wrapped blend of fish, chili paste and other herbs and spices in banana leaf and 'Itek Tim', a very traditional soup from the duck and other vegetables such as tomatoes, salted vegetables, preserved sour plum and flavored with nutmeg [42]. The soul ingredient of the Nyonya cooking is the use of rich and thick coconut milk in the foods which spells out the aroma and cause the dishes to be powerfully flavoured. Basically, Nyonya cuisine contains a few key ingredients which serve as important and spices and condiments. The key ingredients include coconut milk (santan), galangal (lengkuas), (a subtle, mustard-scented rhizome similar to ginger), Pandanus amaryllifolius (laksa leaf) (pandan leaves), dried shrimp paste cake (belachan), tamarind (asam jawa) juice, lemongrass (serai), torch ginger bud (bunga kantan), jicama (sengkuang), palm sugar (gula Melaka); spices such as star anise, cinnamon, cardamom, cloves, nutmeg and leaves such as fragrant kaffir lime leaf (daun limau perut), pandan leaves and many others more 
ingredients [43]. The key ingredients in Peranakans cuisine, communicates the Creole culture of the Peranakan people.

Chief among Nyonya cuisine are their famous and delightful desserts or snacks (kuehs) which are sinfully rich and to break from diets for. Once again thick coconut milk is used. For instance, glutinous rice cake with coconut filling (kueh koci), glutinous rice dumplings (kueh chang Nyonya), and 9-layer steamed cakes (Kueh lapis) [44], glutinous rice (pulut tekan) served with coconut jam (kaya), tapioca cake (kueh bengkang), and a presumably Nyonya signature and must-try dessert (dodol). Dodol is sweet sticky pudding made from glutinous rice flour and coconut cream and comes in different flavours such as palm sugar (gula Melaka) and durian.

The Babas may have introduced to their Chinese forefathers' elements of food preparation techniques to soon be incorporated in Nyonya cuisine such as "stir-frying, braising and steaming" [45] which were adopted by the early Nyonyas, perhaps to provide their Baba Chinese husbands with food much resembling that of south eastern China. Tradition Chinese ingredients and seasonings such as soybean paste (tau cheo), soy sauce and ginger [46], are also part of a Nyonya's expanded cache of ingredient, once again a Baba contribution to their local wives. A combination of local Malay and imported Chinese ingredients and cooking methods culminates in Nyonya cuisine where the best of both worlds are rendered into a "creolized cuisine," as termed by Tan [47]. However, it would be simplistic to assume that a totally hybrid type of cuisine was the result.

Borrowing from the sociological concept of "melting pot", Nyonya cooking is far from an unrecognizable concoction of Malay and Chinese cooking styles, methods and ingredients, but instead is a "salad bowl" cuisine, where individual elements maintain their distinct features, but blending in a harmonious symphony of a new taste experience. For example, results of Chinese stir-frying method to sear meat on high heat, is adapted to release the aroma of Malay-styled chillies and spices paste. Pan fried sambals (blend of chillies and spices) are one such result and are a hallmark of Nyonya cuisine. Tan [48] used the phrase "cultural localization" to describe Nyonya cuisine, which is a result "arising from Chinese and non-Chinese cultural interaction in the context of the Malayan (Melaka) environment".

However, due to Melaka being a port city, its proximity to the sea introduced yet a crucial hallmark of Nyonya cuisine i.e. use of produce from the sea. Apart from the popularity of fish, prawns and squid, Nyonya cuisine include liberal and frequent use of small-sized extraneous shrimps which gets caught in fishing nets. Miniscule shrimps are not wasted but processed into shrimp paste in various presentations. These include the ever popular cencaluk (preserved small shrimps in brine) and belacan (shrimp paste with salt and spices). Nyonya cuisine would never be complete without the use these two ingredients unique to Melaka. The distinctive taste of cencaluk usually makes it suitable as a salad and greens (ulam, Malay influence) dressing but the Nyonya cencaluk omelet will always remain the signature entrée on the menu of any bona fide Nyonya restaurant.

Almost all Nyonya curries would include a generous dose of belacan, usually replacing the total amount of salt used. This shrimp paste is usually toasted in a hot pan (probably influenced by Chinese stir frying method), then crushed and stirred into the Nyonya curry. Use of fresh chillies has long been associated with local Malay cooking but perhaps to help moderate the "untrained" taste buds of early Babas, the pungent chillies were "toned down" with liberal use of shrimp paste, perhaps the origin of the famous Nyonya sambal belacan (chilli paste sautéed with shrimp paste).

The fame of Nyonya cuisine may have stemmed from the upbringing and social expectation of young Nyonyas, who in the early days must be able to cook well in order to qualify as "good " wives and daughters-in-law. Tan [49] even described how a particular young Nyonya would be considered a "capable cook" merely by listening to the rhythm and volume of the pestle pounding against the mortar when crushing chillies.

\section{LOCAL FoOd COMMUNiCATES LOCALTOURISTIC VALUES}

Travel to a unique destination is never complete without sampling local cuisine. Every bona fide traveller or tourist would break loose from their routine and brave themselves to immerse themselves in local food fare. Nyonya cuisine has already made a name for itself in the international food arena. Nyonya food is not new although may be sparse and not readily available or ubiquitous as sushi or pizza. As with its Japanese and Italian counterpart, tourists in Japan and Italy would want sample sushi while in Japan and pizza while in Italy, as with Nyonya cuisine while in Melaka. Tan [50] noted that Nyonya cuisine have been promoted by Malaysia (and Singapore) "as a unique local cuisine" by the tourism agencies of both nations. Nyonya cuisine is unique because, as Tan [50] describes, Nyonya restaurants "allow tourists to consume something Chinese and local, as well as experiencing something Peranakan". The invention of local food for tourism development is Asia's contribution to world cuisine.

Picard \& Robinson [51] wrote that "the observation of and participation in festivals, is an increasingly significant aspect of the contemporary tourist experience." Such would be the experience of tourists when they get to engage in food festivals, namely, Nyonya food festivals. "Festive tourism" is the term used by Picard \& Robinson [52], when they described how Mark Twain (1923) labelled the festivities surrounding the jubilee celebrations of Queen Victoria "worth a long journey to see." Traditional moments of social life such as eating and food can be displayed to tourists for them to absorb. This is very much so an opportunity for the Peranakan community when seeking to "re-assert its identity in the face of cultural dislocation brought about by rapid structural change, social mobility and globalization process [52]. A culturally constructed festival centred on food can result in open avenues to reenact the "security" and homeliness that is traditionally associated with "home" cooking. The symbolic value attributed to Nyonya food may remain as a convenient byproduct of such food festivals. Social connectivity is a positive by-product of festivals when the "meeting of members of such groups," the Peranakans, in this case, brings about a sense of belonging or as Picard \& Robinson 
[53] put it "define 'group inclusion." "The festive practices of eating and drinking, usually contained within restaurants, spill over into the streets, with relaxed social control," [53] may be more appealing to tourists who prefer a less regimented form of experiencing food, much akin to their relaxed mind set "while on vacation." Food festivals allow tourists the "right" to sample volumes of food, beyond their usually dietary or consumption habits, all in the name of "being on vacation." Legally having permission to "violate" norms of eating and dining may actually excite tourists, again in the name of "letting their hair down, while on vacation." As Picard \& Robinson [54] put it, festivals are "socially sanctioned occasions, providing opportunity for organized and symbolic transgressions." Tourists and festival goers become "engaged in a communal feeling of primordial delight, returning to a time when all things appear possible," they added [55]. Festivals provide colour and "moments of spectacle" [55], encouraging tourists to "seize the spectacle, that was made just for them" Picard \& Robinson [56] explained. Indeed the economic benefit of festivals brings benefits to the host community, with new audiences i.e. tourists, lapping up, whatever is served. Cultural creativity in terms of appropriately "packaging" Nyonya food for the consumption of tourists is in itself reenactment of what the post-World War 2 Nyonyas did, in their case, out of necessity, "brought out" Nyonya food from the once protected Nyonya kitchens, once solely reserved for the consumption of only their husbands and children. Appealing to new consumers of Nyonya food, new rules, customer-driven ones, had to be invented, and applied, successfully, in the case of commercialization of Nyonya food. As Said et al [57] put it, Nyonyas have successfully "made their culture, i.e. food, visible to tourists, in a way the latter understands." Notwithstanding this, the consequence of adapting cultural traditions toward tourists is the obvious construction of Nyonya food festivals solely for commercial ends resulting in such festivals a far cry from actual representation of how and what Peranakans routinely eat. It is like telling non-American tourists that Americans eat a full Thanksgiving menu every day of the year.

Many cultural anthropologists including Manderson [58], have agreed that "food is often used in Southeast Asia (as elsewhere) to construct boundaries between social groups". Food consumed by members of a particular ethnic group on an everyday basis would have similarities in terms of preparation and primary ingredients, both much influenced and guided by multiple socio-economic conditions of this community. Similarly food consumed by members of a particular ethnic group in a more lavish and festive occasions do reflect the "best" of this community's culinary preferences. Food prepared and served to invited guests (who do not belong to the same ethnic group) allows the hosts to showcase the "cream of the crop" of their cuisine, usually rendered in more spectacular festive atmosphere, where serving vessels and cutlery unique to the local food further enhances the exclusivity of such entrees, once reserved for members of that ethnic group, but now showcased as the pride, or even status, of the group. Such hitherto secret formula or recipes, tightly kept within members of a particular ethnic group, is shared with all who appreciates them. Notwithstanding of course, some amount of 'trade secrets' which differentiates an expert ethnic chef and mere followers of reproduced recipes. This is when transmission of family and ethnic recipes are handed down from one generation to another, usually well kept within the family. Much pride is associated to bearers of such closely guarded ethnic family recipes, with each generation attempting to maintain the originality and authenticity of these "valuable" (sometimes commercially) know-how. In any given culture, apart from ingredients and the allimportant proportions, cooking utensils, temperature of the stove and duration of each cooking step, are equally important, and closely guarded. This is because the latter would often ultimately make the difference in the taste (and even physical outlook) of the end product.

Bestor [89], vividly describes how the Atlantic Bluefin tuna, landed by American fishermen in Maine, quickly found its way via air freight to Tokyo within hours, highlighting Japan's appetite for sashimi-grade tuna and also used to top the ubiquitous sushi. From the tuna, Japan introduced America and the world its penchant for sushi, which took American by storm in the 1970s, expanding rapidly worldwide in the 1990s alongside Japan's economic expansion and globalized exports of Nintendo, PlayStation, Toyota and Sony, to name a few. The sushi literally went global, consumed in many metropolises worldwide. Bestor [60] aptly describes, sushi is enjoyed at "fifth Avenue restaurants, in baseball stadiums in Los Angeles, at airport snack carts in Amsterdam, at an apartment in Madrid (delivered by motorcycle), or in Buenos Aires, Tel Aviv or Moscow...."

Has the Nyonya's cencaluk or belacan came any close to the global tracks of the sushi? Bestow [61] described how sushi is taken to a new height in Japanese cuisine, with even a sushi university (Sushi Daigaku) in Japan offering short courses in sushi preparation and awarding "imposing" certificates. This remains to show how much pride and cultural ownership sushi can garner to its Japanese heritage. Literally, the art of sushi remains in the hands of the Japanese, yet its appeal is global. Imagine the commercial value of the simple rice gobs topped by tuna. Gross commercialization of sushi need not necessarily translate to poor localization of sushi preparation but instead can be further boosted by the almost "feudal cultural symbol", as Bestor [62] puts it, of an expected "precise and delicate culinary" expectation that diners expect of sushi, and perhaps someday, of Nyonya cuisine. Yet another "world brand" product which capitalized on Asia's use of spice to flavour food is Lea \& Perrins' Worcestershire Sauce. Owned and manufactured by H.J. Heinz since 2005. Its ingredients included the Asian spices of ginger, soy sauce and anchovies. Goody [63], described the origins of the Worcestershire Sauce including its resultant richness in taste and aroma due to a maturing process in the cellar of Messieurs Lee \& Perrins, who placed the excess of the sauce there, having specially formulated the original very spicy early for a single customer, the then retired Governor of Bengal, Lord Sandys. In this case, large case manufacturing of a sauce.

Pierre van den Berghe in Mennell et al [64] highlighted that "commercialization of ethnic cuisine makes its authenticity problematic". In Singapore many Peranakan 
restaurants lay claim to be able to transport the palates of patrons back to the glory days when Nyonyas served the best of their cuisine only to their husbands and children, well within the confines of their homes. This reserved delectable symphony of diligently prepared Nyonya entrees qualify as "authentically prepared" from recipes inherited by young Nyonyas from their matriarchal Bibiks (elder Nyonya), mothers and grandmothers. The Singaporean House of Peranakan Cuisine for example prides itself in its "attempts to root the dining experience of patrons in the shared memories of the Peranakan community" [65]. These Nyonya boasts of chefs and proprietors who trace their ancestry from unbroken line of Peranakan families, ensuring uninterrupted passage of authentic Nyonya recipes from one generation to the next. Rightly so, such Nyonya restaurants, as Wong [66] puts it, "attempts to evoke the Peranakan past in its dishes, a lavish spread of the finest Peranakan (Nyonya) cuisine prepared in true Straits Chinese tradition to relive a heritage of a bygone era". Such is the commercial value and pull of Nyonya cuisine, riding on $21^{\text {st }}$ century advertising and marketing, and validated by cultural linage of the chefs. Historically themed restaurants such as Nyonya restaurants can also draw on the visual and material Peranakan artefacts which inspire the décor of the restaurant in attempt to transport patrons in the private and exclusive dining rooms of Peranakan families of bygone eras. Even the plates and serving utensils are attempted replicas of Baba tableware (porcelain plates, chopsticks, bowls, teacups, spoons etc. bearing Peranakan design motifs). Nyonya cooking has become a valuable tourist-attracting commodity in Singapore and capitalized in almost all marketing material that promotes Singapore as a tourist destination. Peleggi [67] encapsulated this by drawing the example of "the Singapore Tourism Board commodifying ethnic food" such as Nyonya cuisine "as exotica for tourist consumption. What about in Melaka, the ancient city-state where it all first started?

\section{INDEED NyONYA CUISINE HAS TRAVELLED}

The Nyonya laksa (spicy curried noodle soup) made its way from Melaka to Adelaide in the late 1970s and early 1980s as so vividly described by a University of South Australia senior lecturer [68]. She also wrote about how Nyonya recipes "travelled" "from one generation (of Peranakans) to the next; from home kitchen to restaurant; from published cookbooks to kitchen (including kitchen of non Nyonyas); from Melaka to the west and back; and in memory and on the tongue". In a nutshell, Duruz traced the emergence of Nyonya cuisine beyond the vestibules of the Nyonya kitchen, into distant places from Melaka, much with commercial viability. These "landings" of Nyonya restaurants included western nations, where local palates may not have been accustomed to the Malay red-hot chili and heavily spiced curry pastes (sambal), only to be weaned to the world of curries via the less pungent (aided by coconut cream) Nyonya curries; perhaps a full circle when local Malay Melaka wives cooked the very same for their of Baba (Chinese) husbands.

\section{EPILOGUE \& FURTHER RESEARCH}

Duruz [69] used the phrase "culturally desired Other" to describe the desire by the more "powerful" (purchasing power included) "Other" as the Westerner. Throughout history, Anglo-Europeans have expressed their readiness and sense of culinary adventure to try "exotic" foods, especially during the colonization era of the East.

Preparation of food, recipes, even reproduction of ethnic cuisine, reflects identity as Ashley, Hollows, Jones \& Taylor et al [70] noted. "Diasporic communities may experience a sense of connection" to their host community by assimilating part of the latter's traditions, Ashley et al. added. However, eating practices do not only reproduce identity but also construct identities, they expanded. An example would be how Peranakans distinguish themselves from the Chinese via the formers' cuisine. Gillespie in Ashley et al [71] sees this behaviour "as a gesture expressing the desire to establish some degree of independence" from the non-creolized Chinese, nor the local Malays, and to "exert some control" in establishing the Peranakan identity. All these are underlying messages which can be communicated through humanity's love of food and eating.

As cuisines of the world become more ubiquitous, following the lead of the Italian pizza and Japanese sushi, the Nyonya cuisine has already made its presence outside Melaka in great metropolises of the world including London and Melbourne. Further study of the impact of these establishments to its clientele, its intrinsic bearing and impression to both Malaysians and local hosts would be forthcoming; from a perspective of acceptance to indulgence.

\section{REFERENCES}

[1] S. K. Lee, "The Peranakans Baba Nyonya culture: Resurgence or disappearance?" SARI, vol. 26, p. 161, 2008.

[2] S. K. Lee, "A Nyonya precedence," presented at School of Language Studies and Linguistics, Universiti Kebangsaan Malaysia, p. 1, 2009.

[3] C. Y. Ng and S. Abdul Karim, "Historical and contemporary perspectives of the Nyonya food culture in Malaysia," Journal of Ethnic Foods, vol. 3, p. 93, 2016.

[4] J. B. Kuake, "Communicating the Baba-Nyonya cultural identity," Ph.D thesis, Universiti Putra Malaysia at Serdang, p. 46, 2010.

[5] J. B. Kuake, "Communicating the Baba-Nyonya cultural identity," Ph.D thesis, Universiti Putra Malaysia at Serdang, pp. 48 \& 50, 2010.

[6] M. Y. Kee, Peranakan Chinese Porcelain: Vibrant Festive Ware of the Straits Chinese, Routland, VT: Periplus-Tuttle Publishing, 2009, p. 22.

[7] S. K. Lee, "The Peranakans Baba Nyonya culture: Resurgence or disappearance?" SARI, vol. 26, p. 163, 2008.

[8] J. Duruz, "From Malacca to Adelaide...: Fragments towards a Biography of Cooking, Yearning and Laksa," in Food and Foodways in Asia: Resource, Tradition and Cooking, S. C. H. Cheung \& C. B. Tan Ed. New York: Routledge, 2007, p. 187.

[9] G. Hofstede, Culture's Consequences: International Differences in Work-related Values, London: Sage Publications, 1980, pp. 21-23.

[10] J. Mulholland, The Language of Negotiation, London: Routledge, 1991, ch. 1.

[11] S. K. Lee, "The Peranakans Baba Nyonya culture: Resurgence or disappearance?" SARI, vol. 26, p. 163, 2008.

[12] C. Y. Ng and S. Abdul Karim, "Historical and contemporary perspectives of the Nyonya food culture in Malaysia," Journal of Ethnic Foods, vol. 3, p. 93, 2016.

[13] S. K. Lee, "The Peranakans Baba Nyonya culture: Resurgence or disappearance?" SARI, vol. 26, p. 162, 2008.

[14] C. Y. Ng and S. Abdul Karim, "Historical and contemporary perspectives of the Nyonya food culture in Malaysia," Journal of Ethnic Foods, vol. 3, p. 94, 2016. 
[15] S. K. Lee, "A Nyonya precedence," presented at School of Language Studies and Linguistics, Universiti Kebangsaan Malaysia, p. 1, 2009.

[16] K. Lin. (2000). Chinese food cultural profile. [Online]. Available: http://ethnomed.org/clinical/nutrition/chinese_food_cultural_profile

[17] G. M. Americo, "Food and identity: Food studies, cultural, and personal identity," Journal of International Business Culture Studies, vol. 8, pp. 1-7, 2014.

[18] S. K. Lee, "A Nyonya precedence," presented at School of Language Studies and Linguistics, Universiti Kebangsaan Malaysia, p. 1, 2009.

[19] Hall in C. Y. Ng \& S. Abdul Karim, "Historical and contemporary perspectives of the Nyonya food culture in Malaysia," Journal of Ethnic Foods, vol. 3, p. 93, 2016

[20] S. K. Lee, "The Peranakans Baba Nyonya culture: Resurgence or disappearance?" SARI, vol. 26, p. 163, 2008.

[21] C. Y. Ng and S. Abdul Karim, "Historical and contemporary perspectives of the Nyonya food culture in Malaysia," Journal of Ethnic Foods, vol. 3, p. 97, 2016.

[22] C. B. Tan, "Nyonya Cuisine: Chinese, Non-Chinese and the Making of a Famous Cuisine in Southeast Asia," in Food and Foodways in Asia: Resource, Tradition and Cooking, S. C. H. Cheung \& C. B. Tan, Ed. New York: Routledge, 2007, p. 171.

[23] N. Sidek, Pembudayaan makanan Malaysia. Sambutan hari makanan sedunia kali ke-25, Kementerian Pertanian dan Industri Asas Tani Malaysia, Putrajaya (Malaysia). Kuala Lumpur (Malaysia): Agriculture Bank of Malaysia, 2005, p. 94.

[24] S. K. Lee, "The Peranakans Baba Nyonya culture: Resurgence or disappearance?" SARI, vol. 26, p. 165, 2008.

[25] Y. S. Tan, K. Ngah, and L. Abdullah, Negotiation of identity and internal contradictions: The Terengganu and Kelantan Peranakan Chinese foodways compared. Asian Ethnicity, vol. 16, no. 4, p. 1, 2015.

[26] C. Y. Ng and S. Abdul Karim, "Historical and contemporary perspectives of the Nyonya food culture in Malaysia," Journal of Ethnic Foods, vol. 3, p. 102, 2016.

[27] S. K. Lee, "A Nyonya precedence," presented at School of Language Studies and Linguistics, Universiti Kebangsaan Malaysia, 2009. p. 1.

[28] S. K. Lee, "The Peranakans Baba Nyonya culture: Resurgence or disappearance?" SARI, vol. 26, p. 166, 2008.

[29] J. B. Kuake, "Communicating the Baba-Nyonya cultural identity," $\mathrm{Ph} . \mathrm{D}$ thesis, Universiti Putra Malaysia at Serdang, p. 227, 2010.

[30] Levenstein in S. Mennell, A. Murcott, and A. H. van Otterloo, The sociology of food: Eating, diet and culture, London: Sage Publications, 1994, p. 79.

[31] S. Mennell, A. Murcott, and A. H. van Otterloo, The sociology of food: Eating, diet and culture. London: Sage Publications, 1994, p. 20.

[32] C. Y. Ng and S. Abdul Karim, "Historical and contemporary perspectives of the Nyonya food culture in Malaysia," Journal of Ethnic Foods, vol. 3, p. 94, 2016.

[33] C. Y. Ng and S. Abdul Karim, "Historical and contemporary perspectives of the Nyonya food culture in Malaysia," Journal of Ethnic Foods, vol. 3, p. 102, 2016.

[34] S. K. Lee, "A Nyonya precedence," presented at School of Language Studies and Linguistics, Universiti Kebangsaan Malaysia, 2009. pp. $1-2$.

[35] J. Duruz, "From Malacca to Adelaide...: Fragments towards a biography of Cooking, Yearning and Laksa," in Food and Foodways in Asia: Resource, Tradition and Cooking, S. C. H. Cheung \& C. B. Tan, Ed. New York: Routledge, 2007, p. 185.

[36] C. B. Tan, "Nyonya Cuisine: Chinese, Non-Chinese and the Making of a Famous Cuisine in Southeast Asia," in Food and foodways in Asia: Resource, Tradition and Cooking, S. C. H. Cheung \& C. B. Tan, Ed. New York: Routledge, 2007, p. 172.

[37] C. Y. Ng and S. Abdul Karim, "Historical and contemporary perspectives of the Nyonya food culture in Malaysia," Journal of Ethnic Foods, vol. 3, p. 94, 2016.

[38] C. Y. Ng and S. Abdul Karim, "Historical and contemporary perspectives of the Nyonya food culture in Malaysia," Journal of Ethnic Foods, vol. 3, p. 96, 2016.

[39] C. B. Tan, "Chinese Peranakan food and symbolism in Malaysia," in Proc. the 5th Symposium on Chinese Dietary Culture. Taipei, Taiwan, Foundation of Chinese Dietary Culture, 1998, p. 185.

[40] C. B. Tan, "Nyonya Cuisine: Chinese, Non-Chinese and the Making of a Famous Cuisine in Southeast Asia," in Food and Foodways in Asia: Resource, Tradition and Cooking, S. C. H. Cheung \& C. B. Tan, Ed. New York: Routledge, 2007, p. 172.

[41] C. Y. Ng and S. Abdul Karim, "Historical and contemporary perspectives of the Nyonya food culture in Malaysia," Journal of Ethnic Foods, vol. 3, p. 96, 2016.
[42] J. Eveland, "Frommer's Singapore \& Malaysia," Frommer's, p. 98, 2007.

[43] C. B. Tan, "Food and Ethnicity with Reference to the Chinese in Malaysia," in Changing Chinese Foodways in Asia, D. Y. H. Wu \& C.B. Tan, Ed. Hong Kong University Press, New Territories (Hong Kong), 2001, p. 125.

[44] S. Karim and N. Halim, "The Structure of Penang Street Food Culture in Malaysia," in Street Food: Culture, Economy, Health and Governance, C. D. C. V. Cardoso, M. Companion \& S. R. Marras, Ed. New York, NY: Rutledge, 2014, p. 97.

[45] A. J. Aw, "The Peranakan identity: To be or not to be," Ph.D dissertation, University of Oklahoma at Norman, U.S., p. 33, 1994.

[46] C. B. Tan, Chinese Overseas: Comparative Cultural Issues, Hong Kong: Hong Kong University Press, 2004, p. 86.

[47] C. B. Tan, "Nyonya cuisine: Chinese, non-Chinese and the Making of a Famous Cuisine in Southeast Asia," in Food and Foodways in Asia: Resource, Tradition and Cooking, S. C. H. Cheung \& C. B. Tan, Ed. New York: Routledge, 2007, p. 181.

[48] C. B. Tan, "Nyonya Cuisine: Chinese, Non-Chinese and the Making of a Famous Cuisine in Southeast Asia," in Food and Foodways in Asia: Resource, Tradition and Cooking, S. C. H. Cheung \& C. B. Tan, Ed. New York: Routledge, 2007, p. 172.

[49] [49] C. B. Tan, "Nyonya cuisine: Chinese, non-Chinese and the making of a famous cuisine in Southeast Asia," in S. C. H. Cheung \& C. B. Tan (Eds.), Food and foodways in Asia: Resource, tradition and cooking, New York: Routledge, 2007, p. 173.

[50] C. B. Tan, "Nyonya Cuisine: Chinese, Non-Chinese and the Making of a Famous Cuisine in Southeast Asia," in Food and foodways in Asia: Resource, tradition and cooking, S. C. H. Cheung \& C. B. Tan, Ed. New York: Routledge, 2007, p. 181.

[51] D. Picard and M. Robinson, "Remaking Worlds: Festivals, Tourism and Change," in Festivals, tourism and social change: Remaking worlds, D. Picard \& M. Robinson, Ed. Clevedon, England: Channel View Publications, 2006, p. 1.

[52] D. Picard and M. Robinson, "Remaking Worlds: Festivals, Tourism and Change," in Festivals, tourism and social change: Remaking worlds, D. Picard \& M. Robinson, Ed. Clevedon, England: Channel View Publications, 2006, p. 2.

[53] D. Picard and M. Robinson, "Remaking Worlds: Festivals, Tourism and Change," in Festivals, tourism and social change: Remaking worlds, D. Picard \& M. Robinson, Ed. Clevedon, England: Channel View Publications, 2006, p. 11.

[54] D. Picard and M. Robinson, "Remaking Worlds: Festivals, Tourism and Change," in Festivals, Tourism and Social Change: Remaking Worlds, D. Picard \& M. Robinson, Ed. Clevedon, England: Channel View Publications, 2006, p. 12.

[55] D. Picard and M. Robinson, "Remaking Worlds: Festivals, Tourism and Change," in Festivals, Tourism and Social Change: Remaking Worlds, D. Picard \& M. Robinson, Ed. Clevedon, England: Channel View Publications, 2006, p. 17.

[56] D. Picard and M. Robinson, "Remaking Worlds: Festivals, Tourism and Change," in Festivals, Tourism and Social Change: Remaking Worlds, D. Picard \& M. Robinson, Ed. Clevedon, England: Channel View Publications, 2006, p. 18.

[57] D. Picard \& M. Robinson, "Remaking Worlds: Festivals, Tourism and Change," in Festivals, Tourism and Social Change: Remaking Worlds, D. Picard \& M. Robinson, Ed. Clevedon, England: Channel View Publications, 2006, p. 15.

[58] Manderson in M. Janowski, "Feeding the Right Food: The Flow of Life and Construction of Kinship in Southeast Asia," in Kinship and Food in South East Asia, M. Janowski \& F. Kerlogue, Ed. Copenhagen, Denmark: NIAS Press, 2007, p. 1.

[59] T. C. Bestor, "How Sushi Went Global," in the Cultural Politics of Food and Eating: A Reader, J. I. Watson, \& M. I. Caldwell, Ed. Carlton, Australia: Blackwell Publishing, 2005, pp. 13-14.

[60] T. C. Bestor, "How Sushi Went Global," in the Cultural Politics of Food and Eating: A Reader, J. I. Watson, \& M. I. Caldwell, Ed. Carlton, Australia: Blackwell Publishing, 2005, pp. 17-18.

[61] T. C. Bestor, "How Sushi Went Global," in the Cultural Politics of Food and Eating: A Reader, J. I. Watson, \& M. I. Caldwell, Ed. Carlton, Australia: Blackwell Publishing, 2005, pp. 18.

[62] T. C. Bestor, "How Sushi Went Global," in the Cultural Politics of Food and Eating: A Reader, J. I. Watson, \& M. I. Caldwell, Ed. Carlton, Australia: Blackwell Publishing, 2005, p. 20.

[63] J. Goody, "Industrial Food," in Food and Culture: A Reader, C. Counihan," \& P. Van Esterik, Ed. New York: Routledge, 1997, pp. 345-346.

[64] S. Mennell, A. Murcott, and A. H. van Otterloo, The Sociology of Food: Eating, Diet and Culture, London: Sage Publications, 1994, p. 80. 
[65] H. S. Wong, "A Taste of the Past: Historically Themed Restaurants and Social Memory in Singapore," in Food and Foodways in Asia: Resource, Tradition and Cooking, S. C. H. Cheung \& C.B. Tan, C.B, Ed. New York: Routledge, 2007, p. 117.

[66] H. S. Wong, "A Taste of the Past: Historically Themed Restaurants and Social Memory in Singapore," in Food and foodways in Asia: Resource, Tradition and Cooking, S. C. H. Cheung \& C.B. Tan, C.B, Ed. New York: Routledge, 2007, p. 118.

[67] H. S. Wong, "A Taste of the Past: Historically Themed Restaurants and Social Memory in Singapore," in Food and foodways in Asia: Resource, Tradition and Cooking, S. C. H. Cheung \& C.B. Tan, C.B,Ed. New York: Routledge, 2007, p. 124.

[68] J. Duruz, "From Malacca to Adelaide...: Fragments towards a Biography of Cooking, Yearning and laksa," in Food and foodways in Asia: Resource, tradition and cooking, S. C. H. Cheung \& C. B. Tan, Ed. New York: Routledge, 2007, p. 183.

[69] J. Duruz, "From Malacca to Adelaide...: Fragments towards a Biography of Cooking, Yearning and Laksa," in Food and Foodways in Asia: Resource, Tradition and Cooking, S. C. H. Cheung \& C. B. Tan, Ed. New York: Routledge, 2007, p. 186.

[70] B. Ashley, J. Hollows, S. Jones, and B. Taylor, Food and Cultural Studies, London: Routledge, 2004, p. 71.

[71] B. Ashley, J. Hollows, S. Jones, and B. Taylor, Food and Cultural Studies, London: Routledge, 2004, p. 72.

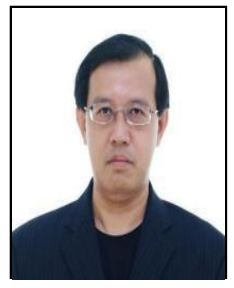

James B. Kuake earned a Ph.D in human communication from Universiti Putra Malaysia in 2010. His masters of arts in communication was from the Ohio State University, Columbus, Ohio, USA in 1987, while his bachelor of arts in journalism was also from the same university in 1986.

$\mathrm{He}$ is currently an associate professor at the Department of Communication, Faculty of Social
Sciences, Arts \& Humanities, Tunku Abdul Rahman University College, Kuala Lumpur, Malaysia. He was previously Dean of the Faculty of Communication, KDU University College, Petaling Jaya, Malaysia, Prior to that he was Department of Communication Head at Sunway University Malaysia and earlier also helmed the Department of Communication at HELP University, Kuala Lumpur, Malaysia.

Dr Kuake's research interest is in micro-cultural issues involving minority communities in Asia; in particular identity issues amongst the Chinese. He is currently researching on the Chinese diaspora amongst minority creole cultural groups in Southeast Asia, particularly that of Generation Y. Born from mixed culture parentage himself, Dr Kuake is a creole of Chinese and Malay cultural origin, going back five generations from Melaka roots.

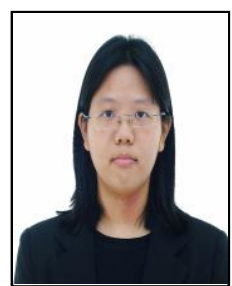

Steffanie G. Kuake earned a master in laws with Merit, majoring in corporate and commercial law from Queen Mary College/ University College London, University of London in 2016. Her Bachelor of Science majoring in Business Administration graduating Magna Cum Laude from South New Hampshire University, USA in 2012.

She is currently a freelance writer and independent author. Currently she is working on a book on her Peranakan heritage. It is a historical fantasy fiction, inspired and drawing from a rich source of the many tales, told to her as a growing up Nyonya by her Peranakan parents and grandparents. She is a sixth continuous generation Peranakan tracing her roots from Melaka.

Ms Kuake's research interest is in areas of Peranakan arts namely, Peranakan patois i.e. Baba Malay, Peranakan poetry and music, traditional costume, jewellery, architecture, furniture and cuisine; in particular those originating from Melaka. 